\title{
El "volver" de la Aurora: \\ sobre el dolor del amor y el conocimiento
}

\section{(The Return of Aurora: On Love Pain and Knowledge)}

\author{
Lorena ROJAS PARMA
}

Recibido: 22 de abril de 2015

Aceptado: 25 de agosto de 2015

¡Coronada de violetas, sonrisa de miel, santa Safo! Alceo de Mitilene

\section{Resumen}

El artículo se propone una disertación sobre el amor entendido como una experiencia ambivalente que incorpora, junto a lo agradable, esencialmente al dolor, y cuya vivencia requiere de una preparación y auto conocimiento. Para ello, he tomado como punto de partida el fragmento 130 de Safo y la noción platónica del alma del Fedro, para culminar en una reconsideración del dolor como una experiencia necesaria que permite la vivencia plena del amor que la poetisa llama "agridulce". El padecer erótico se considera en un doble sentido: desde el dolor profundo que nos lleva a lo abismal, hacia el dolor que se implica equilibradamente con lo "dulce" del amor.

Palabras clave: Eros, dolor, conocimiento, Safo, Platón.

\begin{abstract}
This article proposes a study on love as an ambivalent experience that incorporates, along with the pleasant, essentially pain, and whose experience requires preparation and self-knowledge. To do this, I have taken as a starting point fragment 130 of Sappho and the Platonic notion of soul of Phaedrus, to culminating in a
\end{abstract}


reconsideration of pain as a necessary experience that allows the understanding of what Sappho's calls "bittersweet" love. The erotic suffering is considered in two ways: from the deep pain that leads to the abyss, to the pain that is in balance with "the sweetness" of love.

Keywords: Eros, Pain, Love, Knowledge, Sappho, Plato.

\section{No quiero sufrir}

Hablar del amor en un sentido reflexivo exige siempre alguna mirada desde donde situarse. Es difícil por artificial arrancarse uno mismo de la vida para disertar sobre un asunto tan sustancialmente vital, y que se resiste a la cosificación, cuantificación o alguna pretensión semejante. Diversas son las aproximaciones al amor, por supuesto, y tan valiosas como la fuerza de la intimidad que hace de lo vivido, una experiencia universal. En esta ocasión, para disertar sobre el dolor del amor, y la epistème que se compromete, sugiero el Eros de naturaleza "agridulce", glykýpikron, de Safo, para traer a nosotros la voz poética antigua, primera, con el fin de reflexionar a partir de ella ${ }^{1}$. No ha de extrañarnos que el impulso poético sea la aurora filosófica. De lo agridulce, será lo amargo lo que concentrará la atención y, en adelante, será sinónimo de dolor y oscuridad, del reverso apolíneo de la vida, que de distintas maneras nos ingeniamos en ignorar o negar. En la filosofía, en sus orígenes griegos, escuchamos decir a Sócrates en Banquete que de lo único que sabe es de amor, tras haber proclamado toda su vida que era dueño de una sabiduría que consistía en saber qué era lo que no sabía. Sin embargo, y aunque se trataba del mismísimo Sócrates, esa epistēme suprema del amor no tuvo grandes repercusiones en la filosofía. Y olvidamos que Eros fue, al menos para Sócrates y Platón, el impulso y el entusiasmo necesarios para la epistēme; y en este sentido, como el mismo filósofo lo afirmó, con dificultad se podría considerar un mejor colaborador de la naturaleza humana que Eros².

Decía Voltaire que el amor era "una materia poco filosófica"3. Hallamos, a pesar de esto, reflexiones importantes a lo largo de la historia de la filosofía. Pero sea que estudiemos el atomismo de Lucrecio, las apasionadas cartas de Eloísa o el aneste-

1 Cfr. Luque (2001), frag. 130; Brioso y Villarrubia (2000), pp. 11-78; Carson (1998), pp.105-113; Calame (2002), pp. 20-51; 69-138; 175-189; Calame (2006), pp. 19-35; Fernández, Lasso y Rodríguez (1959), pp. 9-10; 5-89; Ferraté (2000), pp. 236-269; Fränkel (1962), pp. 170-185; Lanata (1966), pp. 63-79; Lesky (1989), pp. 153-174; Page (1955), pp. 8-220; Pedrique (2000), pp. 7-136; Rodríguez Adrados (1971), pp. 5-23; Rodríguez Adrados (1981), pp. 123-142; Rodríguez Adrados (1995), pp. 23 46; 130-146; 174-199; 206-217; Schadewaldt (1973).

2 Banquete, 212b3-4.

3 Voltaire (1995), p. 128. 
siado amor de Spinoza, no hemos podido pasar por alto que el imaginario olímpico lo pensó como un dios y, por lo tanto, como una de esas fuerzas terribles que nos dominan en un sentido absoluto, y ante las cuales, en consecuencia, perdemos todo nuestro poder. Y lo que perdemos en sensatez, lo ganamos en locura. Gracias al Fedro sabemos lo que significa la manía amorosa para la filosofía y, en general, aprendimos que el torrente erótico puede tener un telos epistemológico. Sin duda, ante una comprensión del amor como un poder superior a nuestras fuerzas, los filósofos de todas las épocas debían pronunciase. "Eros, que era un dios para los Antiguos -dice Denis de Rougemont-, es un problema para los modernos" 4 . Más recientemente Lancelin y Lemonnier sostienen: "Es un lugar común fuertemente instalado: el amor y la filosofía no forman buena pareja. Viven en cuartos separados, al menos desde el comienzo de los tiempos modernos"5. Grosso modo, y de maneras muy diversas, hallamos en la filosofía una consideración común: no permitirle que nos haga sufrir. Hacernos inmunes al virus amoroso. Los antídotos han sido diversos: ir por la vida abrazando infinidad de cuerpos, con el fin de diluirse en la banalidad de lo múltiple; solicitando la intervención de la gracia divina para vencer el temible "deseo de la carne"; despotricando contra las mujeres, "egoístas" como la Lou Andreas Salomé de Nietzsche o la "mentirosa y simuladora" de Schopenhauer, que, como es bien conocido, goza de unos cabellos cuya longitud envidian sus ideas. Esto, sólo por mencionar algunos casos famosos. Por vías más o menos razonables, reconocemos en los argumentos amorosos de los filósofos, la prevención ante la saña venenosa de la flecha erótica. No es posible ahora, por supuesto, revisar todas las disertaciones filosóficas sobre el amor, ni es lo que en tan breve espacio nos serviría para reflexionar. Pero ya que vamos a disertar sobre el dolor y lo amargo como lo que también constituye el amor, el Eros de ímpetu epistémico de Platón luce como el más oportuno, pues en él hallamos un reconocimiento de la oscuridad del alma como una de sus fuerzas constitutivas, y una doma difícil de ésta. En lugar de prevenirnos, nos describe al filósofo enfrentándose a ella y haciéndola dócil, y nos muestra la experiencia erótica como una experiencia que hace posible el conocimiento. A partir de los hallazgos platónicos sobre el alma enamorada, serán útiles pasajes del acervo de la filosofía que no se refieren específicamente al amor pero sí a la experiencia que éste implica, de la que vamos a tratar a continuación, aunque sus autores pocas cosas tengan en común.

Disertar a partir de Safo, la autoridad amorosa de todos los tiempos, que no es sensato ignorar, permite unas reflexiones que nos tienden puentes importantes hacia la filosofía. Ella expresó la naturaleza de Eros como la de un "reptil agridulce", órpeton glykýpikron, como una fuerza de condición doble, ambivalente, dulce y amarga. Desde los inicios de las expresiones más refinadas del espíritu, el amor no

\footnotetext{
4 Rougemont (1999), p. 11.

5 Lancelin y Lemonnier (2013), p. 9.
} 
se reveló como una experiencia unidimensional; Safo reconoce que lo amargo pertenece a lo erótico y, que en equilibrio con lo dulce, expresa la plenitud de su naturaleza. En esta ocasión voy a centrar la atención en ese aspecto amargo de Eros por dos razones: i) porque lo doloroso se implica esencialmente en el amor y es lo que, a diferencia de la poetisa, escondemos, negamos, disfrazamos o no reconocemos en él; y ii) porque el dolor de la experiencia amorosa cumple en nosotros, como veremos, un trabajo de epistēme.

Aunque tratemos de "purificar" el amor de la pena, con dificultad dejamos de padecerla, aunque no nos guste reconocerlo. Y el amor como "agridulce" tiene la virtud de acogerla en su naturaleza. Así, si hay algo en esto que nos desagrada, es porque el Eros concebido en estos términos nos confronta. Por tanto, si la naturaleza erótica es doble, tendremos que dar cuenta de ella; aceptar lo amargo y lo dulce como partes de su experiencia. Sin embargo, si no estamos dotados de un alma naturalmente equilibrada, esto resulta una exigencia compleja. Aceptar el claroscuro de la vida nunca ha sido fácil. Por ello, ese consentimiento ante la naturaleza del amor exige un momento previo de reflexión que, como la filosofía, comienza con nosotros mismos. La disertación, entonces, debe volcarse hacia nosotros y la filosofía. Y es cuando Platón nos socorre con su filósofo amante del tercer discurso del Fedro, al que vemos padecer un conflicto consigo mismo que logra equilibrar tras un doloroso proceso. Con todo, el destino de estas breves reflexiones no es una apología de la vida contemplativa del amante platónico, una vez que ha hallado el equilibrio de sí mismo; sino mirar desde la conquista de ese equilibrio, a la manera de un viaje de regreso, lo que permite la vivencia plena del amor, que no ignora su naturaleza ambivalente. En otras palabras, tendremos que atravesar el dolor pero no para erradicarlo de la vida, sino para volver a él fortalecidos. El camino de los grandes maestros del espíritu ha sido la superación del mismo dolor; a nosotros nos queda asumirlo, pero más serenos y reflexivos. Con la conciencia del que sabe, con Heráclito, que la phýsis de todo es la misma. En fin, en condiciones, ahora sí, de abrazar el Eros glykýpikron.

\section{2. "Volver"}

Platón nos narra el inicio del trabajo erótico cuando el amante se encuentra con la belleza que porta su amado, que no es más que la contemplación de la belleza divina que dormía en su recuerdo. Eso produce en el amante una profunda conmoción que altera completamente su vida y, entre otras cosas, lo conduce a un enfrentamiento consigo mismo. La experiencia erótica que el filósofo describe en Fedro, 251a2-252b2, de forma tan vívida y corporal, pasa por una angustia del amante que sólo se apacigua enfrentando ese hondo conflicto. Es con la aparición del amado 
cuando se revela una fuerza del alma de naturaleza violenta y frontal, que desafía dolorosamente a la sensatez y la razón, y que Platón ilustra en el mito con la sugerente imagen de un caballo negro 6 . Esta oscuridad es reconocida y asumida por el amante y, con un trabajo difícil, logra serenarla. Libra una batalla entre fuerzas de sí mismo que se enfrentan y que transitan una doma penosa con ese caballo rebelde que quiere gobernar la vida 7 . Que el amante logre eventualmente serenarse, no significa que su oscuridad haya desaparecido o perdido su vitalidad. Significa que aprendió a ser menos hostil y perjudicial con las otras potencias del alma. Y es sólo tras ese proceso de "conflicto interno", cuando el amante se aproxima al amado desde la calma y el temor que exige un encuentro amoroso auténtico ${ }^{8}$. No sólo las fuerzas intelectuales dominan el amor. Pero es preciso que ese caballo amargo se tranquilice, para que la experiencia erótica se cumpla, esto es, para que el amor, con su ímpetu hacia el conocimiento, permita la conmovedora y reveladora imagen de los amantes como si estuviera cada uno frente a un espejo (katóptrō $)^{9}$ : contemplando la belleza divina que ha vuelto del recuerdo y conscientes de lo que son en un sentido profundo. Esa experiencia de conocimiento es una mirada hacia la interioridad; es una mirada desde el Eros al "conócete a ti mismo" de Sócrates ${ }^{10}$.

\footnotetext{
6 Fedro, $253 \mathrm{e} 2$ y ss.

7 Fedro, 254a1-e8.

8 Fedro, 255a1 y ss.

9 Fedro, 255d5.
}

10 En este sentido, afirma Humbert: "Ocuparse del propio cuerpo es ocuparse de lo que es de uno, no de uno mismo. Ahora bien, sólo es posible ocuparse de sí mismo, es decir de su alma, haciendo suya la sentencia inscrita en el templo de Apolo en Delfos: conócete a ti mismo. Esta conversión a la interioridad es acaso la más original y fecunda de las convicciones fundamentales de Sócrates. Todo el mundo conocía esta expresión, vuelta proverbial a la vez que banal, de la sabiduría apolínea, aunque sin captar el sentido profundo que Sócrates le atribuye... Para Sócrates, este conocimiento interior es la condición necesaria para que el alma se libere por sí misma: sin él, no hay ni conocimiento ni moralidad que sean válidos", Humbert (1995), p. 84. Patočka, a propósito de la reflexión y el cuidado del alma de Sócrates, sostiene que ésta ha de ser "una, sin contradicción, que excluye la posibilidad de estallar en parejas de contrarios y que, en realidad, permanece en contacto con algo duradero, estable”, Patočka (1991), p. 84. Cursivas añadidas. "La preocupación por el alma -continúa el autor-es totalmente interior. El cuidado del alma no quiere formar el alma en ningún acontecimiento exterior; eso es cosa de sofistas. El cuidado del alma es la formación interior del alma misma, su formación como única cosa, inquebrantable y, en este sentido, existente, porque se preocupa del pensamiento", op. cit., p. 85. En medio de la discusión sobre la salud del alma y del cuerpo, Sócrates, en el Cármides, recordémoslo, sostiene que la salud del cuerpo depende del alma; de manera que hemos de concentrarnos en su cuidado: "Pues es del alma de donde arrancan todos los males y los bienes para el cuerpo y para todo el hombre; como le pasa a la cabeza con los ojos. Así pues, es el alma lo primero que hay que cuidar al máximo, si es que se quiere tener bien a la cabeza y al resto del cuerpo. El alma se trata, mi bendito amigo, con ciertos ensalmos (epōdais tisin) y estos ensalmos son los buenos discursos (tàs d'epōdàs taútas toùs lógous einai toùs kaloús), y de tales buenos discursos, nace en ella la sensatez (sōphrosýnēn)", Cármides, 156e5-157a4. Trad. E. Lledó, Madrid, Gredos, 1981. Finalmente, García Baró resume lo que tradicionalmente se conoce de la sentencia délfica y Sócrates: "El dios de 
El amante que se tranquiliza nos deja en claro algunas verdades del alma: el caballo sombrío tiene la potencia de dominarnos, como dice Platón que ocurre al amante cuando no ha logrado apaciguarlo; cuando probablemente desconoce la naturaleza de esa fuerza que sale con violencia a su encuentro, gracias al amor. Sin embargo, esto ocurre con el descontento de las otras dos fuerzas del alma, simbolizadas por un caballo blanco y sumiso y un prudente cochero'11. El alma se enfrenta a sí misma y es cuando reconoce y acepta su indocilidad, a la que somete con mucho dolor, pero con la que aprende a vivir12. El hombre sumido en este conflicto sabe

Delfos saludaba al visitante de su oráculo recomendándole que se conociera a sí mismo. En realidad, esta exhortación lo era a reconocer los límites humanos, a renunciar de antemano a cruzarlos como quien desea temerariamente igualarse a un dios. Pero para poder afianzarse, al modo de Sócrates, en la verdad no sólo creída, sino evidenciada, de que la sabiduría humana apenas es nada comparada con la del dios, es del todo preciso conocerse a sí mismo y conocer los fondos últimos de la sabiduría que quizá atesoran los demás hombres", García-Baró (2004), pp. 193-194. Cfr. Alcibíades I, 132c1-133e2, célebres pasajes en los que Sócrates diserta sobre el "mírate a ti mismo" (idè sautón); Cármides, 164d1-165b4, y la discusión -fallida- de la afirmación que sostiene el "conócete a ti mismo" como "sensatez"; sin embargo, el pasaje más significativo quizá sea, ahora, el de una reflexión platónica posterior, en el Fedro, cuando Sócrates, respondiendo a la pregunta de Fedro sobre la veracidad del mito de Bóreas, sostiene que no tiene tiempo para ocuparse de eso: "Y la causa, oh querido, es que, hasta ahora, y siguiendo la inscripción de Delfos, no he podido conocerme a mí mismo (emoì dè pròs autà oudamōs esti scholē. Tò dè aítion, ō phíle, toúton tóde. Ou dýnamaí pō katà tò Delphikòn grámma gnōnai emautón). Me parece ridículo, por tanto, que el que no se sabe todavía, se ponga a investigar lo que no le va ni le viene. Por ello, dejando todo esto en paz, y aceptando lo que se suele creer de ellas, no pienso, como ahora decía, ya más en esto, sino en mí mismo, por ver si me he vuelto una fiera más enrevesada y más hinchada que Tifón, o bien una criatura suave y sencilla que, conforme a su naturaleza, participa de divino y límpido destino", Fedro, 229e3-230a5. Cfr. Filebo, 48c1 y ss.

11 Cfr. Fedro, 246a3-b7; 253d2-254a6.

12 A partir de Fedro, 253c6, Sócrates recuerda las imágenes del mito que dividen el alma en tres partes: dos con forma de caballo y un auriga. Haré alusión a ello con el fin de dar cuenta del conflicto interno que padece el amante, y del proceso que atraviesa con su parte hostil y frontal. Según la historia de Sócrates, uno de los caballos del alma es blanco, dócil y moderado, mientras que el otro es negro, tosco, chato, de "sangre ardiente y compañero de petulancias" (hýbreōs kaì alazoneías hetairos) (253e3). En los importantes pasajes que vienen a continuación, describe cómo se comporta el amante mientras el cochero del alma logra domesticar al caballo violento: "Así que cuando el auriga, viendo el semblante del amado, siente un calor que recorre toda el alma, llenándose de cosquilleo y de los aguijones del deseo, aquel de los caballos que le es dócil, dominando entonces, como siempre, el pundonor, se contiene a sí mismo para no saltar sobre el amado" (heautòn katéchei mē epipēdan tō erōménō) (253e4-254a2). Sin embargo, el caballo negro, "se lanza, en impetuoso salto, poniendo en toda clase de aprietos al que con él va uncido y al auriga y les fuerza a ir hacia el amado y traerle a la memoria los goces de Afrodita (tês tōn aphodisión cháritos). Ellos, al principio se resisten irritados (...) Pero, al final, cuando ya no se puede poner freno al mal, se dejan llevar a donde les lleven, cediendo y conviniendo en hacer aquello a lo que se les empuja" (254a3-b4). Así, inicialmente, la mejor parte del alma cede al impulso hacia el amado, al punto decisivo de recordar "los goces de Afrodita". Con todo, es de esa forma como el alma logra contemplar el "rostro resplandeciente" del amado. Es entonces cuando el auriga recuerda la Belleza de antaño (254b5), y cuando "tira hacia atrás de las riendas, tan violentamente que hace sentar a los caballos sobre sus ancas" (254c3-4). Por supuesto, el caballo blanco no se resiste; el negro, sí. Y tras gritar injurias a sus compañeros -los acusa de "cobardía" y 
que no puede destruirla, que es una fuerza que lo constituye, pero al reconocerla, enfrentarla y, lo más importante, no rechazarla, impide que ejerza su pleno dominio sobre la reflexión y la sensatez. En adelante, cuando el caballo negro esté en presencia del amado, padecerá temblores, dice Platón ${ }^{13}$, y lleno de miedo cederá ante la epistème que des-cubre lo que reposa en las almas enamoradas. Curiosamente, la vehemencia que se dibuja en ese caballo oscuro del alma, padece en presencia de la belleza divina algo que recuerda el "temor y temblor" de San Pablo, con el que debemos trabajar en nuestra salud y salvación; como si desde siempre se nos estuviera enunciando que esa parte de nosotros, con su estremecimiento, vitaliza con su dolor nuestras búsquedas y conquistas. Por eso el amor no es sólo prudencia e intelecto. Es en este sentido que la experiencia plena de lo erótico, como la enuncia Safo, implica un trabajo que eventualmente logra el equilibrio de ese claroscuro de caballos, de las fuerzas contrarias que son lo agridulce de lo erótico y que Platón vuelca de manera muy aguda en el ama humana. La ambivalencia de Eros es la

\footnotetext{
"debilidad" (deilía kaì anandría)-, Sócrates afirma lo siguiente: "Y, de nuevo, obligando a acercarse a los que no quieren, consiente a duras penas, cuando se lo piden, en dejarlo pasar otra vez" (254d12). A estas alturas, la mejor parte del alma se ha fortalecido, y logra persuadir al caballo hostil de que lo deje para una próxima vez. Esa próxima vez, en efecto, llega, y el caballo hace su demanda; obliga a sus compañeros a volver hacia el amado, pero el auriga -ahora sí- aplica la violencia contra el rebelde: le arranca el freno de los dientes y le llena de sangre la lengua y las quijadas, mientras clava las patas y la grupa en la tierra. Es sólo cuando "el mal caballo ha tenido que soportar muchas veces lo mismo, y se le acaba la indocilidad, humillado, [cuando] se acopla, al fin, a la prudencia del auriga, y ante la visión del amado, se siente morir de miedo" (254e5-7). Es ahora cuando ha triunfado la parte buena del alma sobre su parte inferior, desenfrenada y frontal. Sin embargo, este acoplamiento no apaga del todo la fogosidad del caballo negro. En efecto, tras el proceso delicado de aproximación al amado, ocurre lo siguiente: cuando el amado desea a su amante, y desea acostarse a su lado, "el caballo desenfrenado del amante tiene algo que decir al auriga, pues se cree merecedor, por tan largas penalidades, de disfrutar un poco" (255e1-3). Incluso después de todos esos sufrimientos, aún el caballo pide ser complacido. No obstante, el alma del amante, si se ha entregado a la filosofía y la contemplación, mantendrá subyugado este ímpetu y mantendrá en libertad a su parte superior. Puede ocurrir, sabemos, que algunos amantes que lleven una vida "menos filosófica", en estado de embriaguez o de descuido, cedan a sus deseos y sus caballos desenfrenados triunfen de nuevo. Así, la parte indócil del alma, si bien logra estar subyugada y sometida, no deja de manifestarse haciendo sus reclamos, los que, progresivamente, van siendo menos agresivos. Ese sometimiento, como vemos, no ocurre desde el inicio: antes de comenzar a persuadir al caballo negro, éste logra arrastrar al auriga y a su compañero blanco a sus dominios. En este sentido, si bien hay un sometimiento final, hay un proceso difícil con el ímpetu del alma, que merece la pena resaltar antes de la concreción de ese sometimiento. Antes de la persuasión, la docilidad del caballo blanco y el conductor del alma son arrastrados por la fogosidad que los acompaña; y con persuasión y sangre -una vez que el auriga ha recordado la magnificencia de la Belleza-, la fogosidad es subyugada. No obstante, ese sometimiento no ahoga la naturaleza rebelde pues, ahora sin improperios, hace de nuevo su demanda, pero obedece sin protestar cuando el caballo blanco y el auriga "se oponen a ello con respeto y buenas razones" (2556a). Cfr. República, IV, 439d; 440a y ss.; IX, 508a y ss.; cfr. Ferrari (1992), pp. 262-268. La traducción de Fedro es de E. Lledó, Gredos, Madrid, 1997; y el texto griego, de la edición de Maltese (2010).

13 Cfr. Fedro, 254e1-3 y ss.
} 
ambivalencia del alma. Platón sabe que la vida en medio de esa dualidad, requiere ser equilibrada.

Ahora bien, estas disertaciones guardan algún sentido si nos referimos a la experiencia de un amor que, desde Sócrates y Platón, podemos distinguir como auténtico. Es preciso distanciarlo de encuentros banales, pasajeros, que intentan evadir la soledad, o del hombre simple que deambula de cuerpo en cuerpo con un vacío que no está en condiciones de sanar14. Bien sostiene Voltaire que "se llama falsamente amor al capricho de algunos días, a una relación ligera, a un sentimiento al que no acompaña el aprecio, a una costumbre fría, a una fantasía novelesca, a un gusto al que sigue un rápido disgusto, en una palabra, se da ese nombre a una multitud de quimeras"15. A renglón seguido y sin más explicaciones, nos manda a leer el Banquete platónico. Al menos sostiene que no todo es amor, aunque así se pretenda llamarlo. Algunas advertencias nos permiten sostener, además, que no a todos alcanza la vivencia erótica auténtica. Así, la experiencia amorosa del amante del Fedro le ocurre sólo al filósofo, lo que sugiere que el conflicto reflexivo a que nos invita el amor, no sucede a la totalidad de las almas. En el Banquete, Platón hace decir a Aristófanes que sólo los que no guardan hybris en su corazón serán favorecidos por un Eros terapéutico que les permitirá el hallazgo de su "mitad" perdida. En realidad, sólo la experiencia de un amor genuino puede acompañarnos en una reflexión que reconoce en lo erótico el ímpetu del conocimiento. Ese amor no tiene nada que lo calibre más que la propia experiencia, que lo reconoce con la certeza del hallazgo. No en vano Platón lo describe en medio de la profunda convicción que también supone la anamnesis.

He mencionado a Sócrates para referirme a un amor auténtico, no para argumentar con él la fuerza amarga y oscura de Eros. Él es el filósofo erótico por excelencia, por ello exige un momento de nuestra atención. Para Sócrates, dueño de una exigente concepción de lo erótico, sólo se ama lo realmente bueno, pues no es posible desear lo malo ${ }^{16}$. Si dijésemos lo contrario, no sabríamos qué es el deseo y

\footnotetext{
14 En este sentido, recordemos el "amante" que "ya no es tan novicio", del Fedro 250e1-5, como uno de esos ejemplos que no cuenta en la apreciación del amor que ahora se presenta. Aquel "enamorado" no se deja llevar "para donde está la belleza misma, por el hecho de mirar lo que aquí tiene tal nombre, de forma que, al contemplarla, no siente estremecimiento alguno..." No tiene la menor sensibilidad por la Belleza en sí y, como dice el pasaje, desconoce la experiencia del estremecimiento ante su presencia. Más aún, no está en condiciones de "reconocerla". Sólo mira lo que aquí, en el mundo del devenir, se nombra bello. Esto es cambiante, mudable, perecedero, de manera que lo que ama está lejos de la serenidad y estabilidad de lo que es realmente amable -la Belleza-. Entonces, como un cuadrúpedo (tetrápodos), entregado al placer, pretende "cubrir y hacer hijos" (baínein epicheirei kaì paidosporein), y ya "ni teme ni se avergüenza de perseguir un placer contra naturaleza (parà phýsin hedonēn diōkōn)”. Sumido en la pluralidad y el devenir, no puede amar la serenidad de la Belleza.

15 Voltaire, op. cit., p. 130.

16 Cfr. Gorgias, 468b2-d1-5; Menón, 77c11-e9; Banquete, 206b1-3. Cfr. Boeri (2007), pp. 44 y ss.
} 
menos aún qué es lo que deseamos. Hay que conocerse muy bien, en consecuencia, para saber qué es lo que se desea, y es preciso saber para poder distinguir lo bello en apariencia de lo verdaderamente bello, pues lo verdadero es lo que se ama. Desde ese refinado y complejo conocimiento de uno mismo y de lo bueno, no erramos y, así, no sufrimos. No hay tal cosa como un "errar" en el amor; lo que hay es un desconocimiento de uno mismo y de lo que realmente se ama -lo bueno y lo bello-- Lo demás termina diluido en la banalidad ilusoria de la apariencia. El lector de los diálogos tempranos de Platón, y de Banquete, conoce la fuerza de estos argumentos. Sabemos que el alma examinada y atenta de Sócrates no estalla en contrarios; en equilibrio consigo misma y con la vida, sabe lo que es amable. Sócrates tenía el agudo sentido del saber "distinguir" (diagignōsko) para serenarse en lo verdadero ${ }^{17}$. Su fuerza estaba en el hondo conocimiento de sí mismo y, con ello, en el dominio de sus ímpetus, en el saberse tanto que logró concebir el alma -y según los testimonios, vivirla- como una unidad en equilibrio.

Con todo, no cabe duda que sintió el estremecimiento erótico ante el amado; recordemos sus escenas con Cármides en el gimnasio, en las que sudaba ardoroso imaginando lo que había dentro de su túnica ${ }^{18}$. Pero se cuidó al punto de no involucrarse, incluso en situaciones límite ${ }^{19}$. Sócrates es el filósofo erótico, no el distendido que se abandona a Afrodita, salpicada de banalidad. Traer a la memoria su célebre episodio con Alcibíades es más que suficiente: a pesar de estar acostado junto al joven, querido por el filósofo durante muchos años, dispuesto a "conceder sus favores" a Sócrates, éste mantuvo incólume su contención. Tiempo después Alcibíades cuenta públicamente esta historia, ebrio y receloso, mientras confiesa que aquella mañana despertó "como si hubiese dormido con su padre o su hermano mayor"20. La estrategia filosófica de Sócrates incluía la seducción de sus bellos interlocutores, al punto de hacerlos sentir "narcotizados" 21 , sin hacerse cargo luego de la herida erótica -"mordisco de víbora" la llama Alcibíades- que había propiciado. La atmósfera erótica que favorecía Sócrates tenía como fin impulsarse en la búsqueda filosófica, que era una exploración del alma ${ }^{22}$, no una distención sexual. El filósofo halló la fuerza del maestro, la del hombre "bueno", que ya no necesitaba de nada. Y ese es un caso, por supuesto, extraordinario. Habría que preguntarse, sin embargo, por la experiencia de Alcibíades -y él dice que también por la de otrosque no fue así de serena. Siempre es curioso ver a Sócrates inconmovible ante la muerte, pero sudando frío y confundido cuando el bello Cármides se le aproxima.

\footnotetext{
17 Cfr. Protágoras, 356e1-2.

18 Cfr. Cármides, $155 \mathrm{c} 3$.

19 Cfr. Banquete, 218c1 y ss. Rojas Parma (2011).

20 Banquete, 219d1-2.

21 Menón, 80a7.

22 Cfr. Teeteto, 143d-144d.
} 
Pero, volvamos a los poetas un momento, y recordemos que Teognis también llamó pikrós kai glykýs a Eros, además de atrayente (harpaléos) y cruel (apenēs). Pero su fragmento (1353-1357) afirma que si el deseo se cumple, entonces es dulce (glyký), si no, es una gran tortura (aniērótaton). Si bien el poeta también reconoce que el amor es amargo y dulce, Safo reveló lo erótico en lo que expresó significativamente una sola palabra: glykýpikron. La poetisa logró captar que la experiencia amorosa es como el sobresalto sudoroso pero encantador, que lo dulce y lo odioso están siempre, en el mejor de los casos en equilibrio, en el clima tenso que domina Eros. Y esto nos recuerda a Sócrates en sus diálogos. No debe ser falso que Platón haya llamado a Safo "la décima musa". Por supuesto que veremos la peor cara del dios cuando, al decir de Anacreonte: "De nuevo Eros me golpeó como un herrero con una enorme hacha, y me puso a lavar en un tempestuoso torrente"23. Imagen lo suficientemente fuerte como para agregarle algo. Y es cierto que también estaremos envueltos de felicidad como Abelardo y Eloísa en sus buenos tiempos. Pero lo que quiero resaltar es, justamente, lo que sostiene Teognis en dos líneas sobre su amado: "Mil males penden de él, pero también mil bienes: precisamente en esto hay un cierto deleite"24. Ese es el quid del amor: ese deleite (cháris) que surge de lo agridulce. Sócrates, al ser liberado de los grillos de sus piernas, en su celda y en los predios de la muerte, dijo, con cierto tono de asombro, que el placer y el dolor son como un animal cuya cabeza tiene dos caras: donde está uno, está el otro ${ }^{25}$. Que hallemos deleite en ese equilibrio de la "fórmula" de Teognis o en el amor de Safo, es lo que implica el alma lúcida y reflexiva de la que estamos hablando.

Probablemente lo sano sea reconocer en la experiencia erótica ese equilibrio, y renunciar a imágenes unidimensionales que la vuelven una fantasía vaporosa cuyo destino es, por supuesto, una caída a tierra estrepitosa. Alejados de la realidad vital, no estamos preparados para hacer frente al lado sombrío y doloroso que viene a nuestra vida cuando hemos abrazado la realidad del amor. No ha faltado razón a los filósofos para precavernos ante Eros. Sin embargo, la vida sin una profunda experiencia amorosa, que quiebra y enriquece el espíritu, es una vida pobre, sin relieve y, lo más importante, una vida que se ignora a sí misma. A propósito de un comentario a Schopenhauer, dicen Lancelin y Lemonnier: "el corazón que no se rompió se va endureciendo poco a poco"26. El mandato socrático "conócete a ti mismo" sólo es posible con el otro, pues exige el diálogo; y, reconociendo los hallazgos de Platón, sólo es posible amando. Así, si una vida sin examen no merece la pena ser vivida, como decía Sócrates, una vida sin amar, tampoco. Eros agridulce se vuelve

\footnotetext{
23 El fragmento 17 (45D) pertenece a la Antología de la poesía lírica griega, Madrid, Alianza, 2001, p. 108, de C. García Gual.

${ }^{24}$ Los dados de Eros, Madrid, Hiperión, 2000, frag. 1369-1372. Trad. Aurora Luque.

25 Cfr. Fedón, 60b3-8.

26 Voltaire (1995), p. 139.
} 
el camino tormentoso que implica conocerse a uno mismo. En medio del amor, la amargura y las turbulencias empiezan a develarse; el alma comienza, en su movimiento vital, a mostrar sus grietas, sus desbordamientos, sus ciclos ciegos y repetitivos, sus rutinas de tristezas heredadas. Pero cuando la experiencia es lúcida y provechosa, comenzamos a hacernos conscientes y a saber de nosotros lo que de otra manera, quizá, habría permanecido enterrado. Ocurre lo que Sócrates exigió siempre a sus interlocutores: volver la mirada hacia sí mismos, con el fin de "cuidar el alma". No abandonamos el hallazgo socrático del cuidado y la atención que nos debemos a nosotros mismos, si somos reflexivos y estamos atentos a nuestro êthos. Nada más penoso que ver al otro mostrarse como un caparazón lleno de hábitos, totalmente ausente de sí mismo.

De esta manera, podemos recordar que el "volver" del "viajero que huye" y que regresa sintiendo que veinte años no son nada, es siempre un volver a nosotros mismos. Y allí de vuelta, gracias al amor, nos hallamos, nos topamos con lo que realmente somos, oculto tras los velos de Maya que nos engañan incluso dentro de nosotros, y ocurre que nos asombramos ante el hallazgo. Y si nos asombramos, empezamos a filosofar. Razón lleva Manuel Cruz en su libro Amo, luego existo, cuando muestra que el asombro que da origen a la filosofía, como lo dijeron Platón y Aristóteles, implica un previo amar; pues sólo el que ama, es capaz de asombrarse. ${ }^{27}$ Amo, me asombro, luego pienso. Y ese primer asombrarse al que hago referencia con el amor, es con uno mismo, de manera que el filosofar comienza realmente allí. Y esto no es más que recordar la vieja y conocida sentencia de Heráclito: "me investigué a mí mismo", por no citar de nuevo el mandato socrático, cuyo origen es Delfos. Ese "volver" lo veremos desde diversas perspectivas a lo largo de la historia de la filosofía. El tino de Platón fue haber descubierto el amor como lo que nos despierta del letargo y hace posible el conocimiento. Haber hecho del alma que conoce, un alma erótica.

\section{Hacia la Aurora}

Este amar, asombrarse y luego pensar, implica entonces un recogimiento reflexivo que nos exige el tránsito de un camino difícil. El pensamiento siempre nos apasiona y nos angustia. Y esto se nos devela como un movimiento erótico. Desde la consideración del dolor que ahora nos ocupa, y que compromete el conocimiento propio, el amor nos invita a "excavar" en nosotros para ir des-cubriendo lo que tapias pesadas de maneras aprendidas y huecas -hábitos sin fundamento- han enterrado como el tiempo a las ruinas que esperan ser halladas. El mismo Platón ha dicho que el estremecimiento más fuerte que debe enfrentar el amante, es consigo

27 Cruz (2013), p. 14. 
mismo. Y es que reconocer la plenitud agridulce de Eros, es ya un reconocimiento propio. El amor siempre está dirigido a alguien o al algo, es cierto, pero eso no nos exime de un trabajo en solitario; de emprender un camino que sólo podemos recorrer nosotros, como le ocurrió al filósofo amante del Fedro. Y aquí comienza la más grave función epistemológica de lo erótico. No hay, por supuesto, una única manera de abrazar esta experiencia. Pero hay algo común en el "volver" hacia uno: enfrentar lo desconocido o temido, ocuparse de los hallazgos, para regresar más humildes y reflexivos. Esos procesos me han evocado siempre una imagen de descenso, de ir hacia el fondo de uno. Por ello lo que llega a mi espíritu en medio de estas disertaciones, es el precioso aforismo con el que Nietzsche comienza Aurora, en el que anuncia su trabajo de minero, de hombre que horada para adueñarse de misterios y oscuridades, y así lograr el camino del regreso, de la redención, "su propia aurora". Tener la valentía de mirarse a uno mismo, con lo penoso que resulta, implica un poco esta experiencia, aunque no contemos con los talentos del filósofo.

Robemos de Aurora este conocido pasaje:

Este libro es la labor de un hombre subterráneo, de un hombre que cava, horada, que mina. Verán los que tengan hechos los ojos a estas exploraciones en las profundidades, como avanza lentamente ese hombre, con que suave inflexibilidad, sin dejar ver la molestia que supone toda larga privación de aire y de luz. Podría considerársele satisfecho de su oscuro trabajo. ¿Será que alguna fe le conduce, que algún consuelo le indemniza de sus penas? ¿Querrá rodearse de una densa oscuridad que sea suya, hacerse dueño de cosas incomprensibles, ocultas, enigmáticas, sabiendo que de ahí ha de salir su mañana, su propia aurora $?^{28}$

Por supuesto Nietzsche no escribe estas líneas tan fuertes buscando el subsuelo del amor, sino el de sí mismo, el de la filosofía y su "fe en la moral". No es éste un texto amoroso, pero nos marca el camino hacia las propias honduras, la ruta temeraria hacia las propias sombras, haciéndose dueño de ellas -no rechazándolas-, aceptando lo misterioso y hasta lo incomprensible para, desde allí, conquistar "su propia aurora". Y este proceso, estoy diciendo, sí se implica en el amor. Su labor de episteme es una horadada nocturna de la que se regresa con el alma serena del amante. Eros agridulce es subterráneo, su "agitar de los sentidos como en el monte se arroja a los pinos el viento", al decir de Safo, remueve las murallas profundas de nosotros agrietándolas y dando a lo que allí se oculta una esperanza de vida. Nietzsche hace su labor de Trofonio, como él mismo lo proclama, en la más temible soledad: "Descendí a lo profundo; me puse a horadar el fondo". No es amor lo que busca, es cierto, pero el amor deambula por esas entrañas que el filósofo del martillo merodea orgulloso. El dolor erótico que se enfrenta lo sentimos surgir de

28 Nietzsche (1981), p. 1. Cursivas del autor. 
ahí, mientras quebranta su encierro y se hace dueño de su "oscuro trabajo"; trae a la luz lo confinado y lo pone frente a nosotros. Cuando ocurre el padecer de alma quebrada, de vida hecha trizas, se hace la labor del filósofo y somos lanzados a ese abismo donde iremos a "indemnizar las penas". Eros es el "reptil" que se arrastra en esos subsuelos, y se nos devela cuando nos deja desmayados y estremecidos. En esa imagen Safo plasmó la ambivalencia, la duplicidad de una fuerza vital que nace y renace, que destruye y crea, que se arrastra por nuestros propios desiertos. En la horadada de Nietzsche deambula Eros y la raíz del dolor que padecemos cuando nos toca sufrir.

Sin embargo, esto sirve de algo si consideramos que desde ese descenso es posible hallar la brecha hacia el equilibrio del alma. ¿Para qué otra cosa serviría sumirnos en esa oscuridad si no para desentrañar sus secretos? Pero ese eventual hallazgo de una fisura que puede volverse camino, ese rayo olímpico que ilumina con violencia la noche, requiere de algo que lo provoque. Nunca salimos de la ceguera gratuitamente. Y una experiencia erótica, con el dolor que implica y que se enfrenta, es una de esas vivencias con la capacidad de estremecer lo más abismal del espíritu. Para hacer de Trofonio hay que saber que se va horadando el subsuelo para hallar, eventualmente, un tesoro. Y hacernos incluso adivinos. Decía Schopenhauer que para volver hacia uno mismo hay dos caminos: uno que exige la "perfecta bondad de alma", para así adueñarse de todos los dolores del mundo; y otro que supone padecer un "inmenso sufrimiento" o un "aplastante dolor". Y como el primero es el camino de Buda, parece que lo que nos queda es sufrir. En palabras del filósofo:

Cuando ha logrado recorrer todos los grados de la creciente angustia, cuando, después de una resistencia suprema, llega a tocar el abismo de la desesperación, el hombre vuelve a entrar súbitamente en sí mismo, se conoce, conoce el mundo, se transforma su alma, se eleva por encima de sí misma y de todo sufrimiento $[\ldots]^{29}$

Esa es la brecha que abre el dolor. La posibilidad de la redención. El padecer asumido e incorporado que hace las veces de Hades llevando violentamente a Perséfone al reino de la muerte, mientras lo embellece con su presencia. El mismo Schopenhauer habla de la "llama purificadora del dolor". Por supuesto que un desastre amoroso puede llevarnos a los rieles del tren de Ana Karenina, imagen conocida que ahora nos resume las mil tragedias que podrían sobrevenir. Pero, aun-

29 Los dolores del mundo, Buenos Aires: Prometeo, 2013, p. 53. Esa conciencia del "inmenso sufrimiento" de Schopenhauer es muy lúcida para expresar las labores de Eros en nosotros; aunque su concepción amorosa implique, en realidad, un telos mucho más concreto: la reproducción de la especie. El filósofo se pregunta "¿Qué es el amor?” Y responde sin ambigüedad: "es la voluntad que aspira a vivir en un ser distinto y nuevo". Asimismo: "El único fin verdadero -dice-, el fin real de toda unión de amor, es engendrar un hijo; aunque los amantes no sospechen la traición de la Naturaleza, que, en tales ocasiones, sabe cubrirse con una máscara", pp. 87-88. 
que hayamos llegado a la estación, aún nos aguarda la posibilidad del dolor redentor de nosotros mismos. Eros agridulce tiene este poder: y si hemos alcanzado el quiebre del tormento, que puede volverse un camino hacia nosotros, es porque lo dulce del agridulce ya nos acarició la existencia. Ahora no me refiero al tormento del deseo no consumado, del que habla Teognis. Si la experiencia nos despertó y nos detuvo, nos hizo demorarnos en el silencio de la reflexión, es porque la hemos asumido en toda su plenitud. Porque hemos permitido que el corazón de la vida nos afecte, hasta la desesperación de la transformación, y no hemos hecho de la existencia un cúmulo de días de repetición ordinaria e idéntica, incapaz de lograr en nosotros el recogimiento requerido para asombrarnos y pensar. Si seguimos siendo los mismos a pesar de todo, si seguimos repitiéndonos como almas sin juicio, permaneceremos encerrados en un ciclo ciego e interminable que tanto estupor le causó a Platón, y que vemos plasmado en las sugerentes imágenes de los infiernos orientales. Es más honroso cavar con Nietzsche, por lento y penoso que resulte, que terminar aplastados en la estación del tren o anestesiar la vida banalizándonos en la multiplicidad, que siempre es pobre. Razón lleva Platón cuando distingue al amante del que se comporta como un tetrápodos. También Diotima, quien para banalizar el amor a los cuerpos y fortalecer la belleza amable de las almas, recomienda el amor a "todos los cuerpo bellos" (pánton tōn kalōn sōmátōn erastēn) ${ }^{30}$. Esto tiene un aire de familia con la historia de Don Juan, que junto a la de Tristán, dice Denis de Rougemont, protagoniza el mito amoroso de Occidente. En Don Juan hallamos un devorador de cuerpos sin pasado ni futuro, sin ninguna hondura, sin lugar donde horadar. De él dice el autor que "nunca accederá al erotismo, que es la superación del instinto y de las hambres animales. No interesa más que los apareos de otros, y no tiene prestigio para la imaginación" 31 . Si bien Don Juan supone el contexto de la cultura cristiana, con sus reglas a quebrantar, percibimos la ausencia de la experiencia erótica.

El Eros del Fedro, antítesis de esas ligerezas, no es un reptil agridulce como el de Safo, pero es la fuerza maniática que agita las potencias del alma que se enfrentan en un conflicto que sí es agridulce y que realmente nunca se ausenta. Si bien el Eros de este discurso platónico no es doble ${ }^{32}$, la ambivalencia erótica no desapare-

\footnotetext{
30 Banquete, 210b4-5.

31 Rougemont (1999), pp. 123-124.

32 Cfr. Banquete, 180c-189b. Allí Platón considera la naturaleza doble de Eros a través de los discursos de Pausanias y Erixímaco. En el caso del primero, hay una petición de proscripción de lo que es acusado por él como Eros pandemos, al igual que su compañera Afrodita. Y, en el segundo, hay un Eros enfermo que es preciso erradicar. En ambos casos, y a diferencia de lo que ocurre en el alma del amante del Fedro, el lado "malo" de Eros ha de ser exterminado en lugar de educado, domesticado o calmado. Parte de la agudeza platónica probablemente radique allí: en destacar que lo "oscuro" de lo erótico se tranquiliza, con mucho esfuerzo, pero no desaparece ni se extirpa pues, desde su ímpetu natural, vivifica y mantiene en tensión la relación amorosa.
} 
ce, pues se vuelca hacia nosotros en tanto que lo agridulce y lo claroscuro constituyen las fuerzas del alma. En ésta podemos concebir la naturaleza de lo erótico, desde donde es posible la propia epistème, la del mundo y de la verdad trascendente que se recuerda y se contempla. Así, el hombre que conoce, es un hombre erótico. Es el que ama y luego piensa. Hablo, por supuesto, del filósofo. Por ello es necesario hacer una precisión: estamos ante el alma erótica, la que ama y conoce, sólo cuando el proceso de doma del caballo oscuro ha ocurrido, cuando su instinto violento y frontal ha sido apaciguado, cuando se ha hecho el trabajo reflexivo que equilibra sus fuerzas. Ese equilibrio que preside el lógos, se auxilia con la sensatez y cuenta con la vitalidad de lo que ha de someterse. Tal es el alma erótica que se orienta hacia el conocimiento, la que hace posible el hallazgo de "lo verdadero".

Esto significa, entonces, que el "descenso" hacia lo amargo y lo oscuro no tiene necesariamente un fin trágico. Por el contrario, enfrentar con pena el caballo hostil, puede ser el camino, al decir de Nietzsche, de la propia aurora. Una aurora que nos abre hacia la luz de la vida y del amor. Así como el filósofo amante se equilibra, es posible volver a la luz después de padecer la aventura del minero. Nietzsche regresa a contarnos sus hallazgos; declara que un hombre tras esa vivencia ya no puede callar. Schopenhauer describe la experiencia del "dolor aplastante" como lo que nos lleva al abismo de la desesperación, pero desde donde regresamos liberados del sufrimiento. Ese retorno de las sombras recuerda, por supuesto, la historia de Perséfone. Su regreso a la luz después del rapto que contra ella acometió Hades, no es un regreso definitivo; en realidad, su experiencia no abandona la condición claroscura de las cosas. Vuelve periódicamente a la tiniebla que ya le pertenece, y en la que ahora es una reina. El ritmo de luz y oscuridad de la diosa nos sugiere que la experiencia vital, tan poderosa como la erótica, ha de dar cuenta de estos contrarios inevitables. Ellos constituyen el equilibrio. Perséfone no se entierra para siempre en la penumbra ni contempla de por vida la luz del sol. Ella es la imagen de que la madurez ganada, la fortaleza adquirida, no son gratuitos: el dios más abominable la condujo a su abismo. Ella es la imagen del renacimiento del que somos capaces, si nos hacemos cargo de nuestro infierno.

Como Nietzsche nos ha llevado a su Aurora, nos ha llevado también al hermoso himno del Rig Veda del que toma su nombre, donde escuchamos al poeta decir:

¡Levantaos! Ha venido a nosotros el espíritu de vida [la Aurora]; la tiniebla se ha retirado; llega la luz. Cede el camino al sol para que avance. Hemos alcanzado aquel momento, en que le conceden los Dioses una nueva etapa a nuestra vida. ${ }^{33}$

Y en otro verso, afirma: "Así como la Aurora es puesta en marcha, para que surja el sol, así la noche se ha retirado ante la Aurora". ${ }^{34}$ Ella abre los caminos lumi-

33 Himnos del Rig Veda, Buenos Aires: Las Cuarenta, 2014, Frag. 16. Trad. Fernando Tola.

34 Frag. 1. 
nosos mientras aparta la tiniebla, pero alterna sus colores; siempre llega una nueva aurora. Y desde ese comienzo al que -paradójicamente- llegamos con más luz, podremos amar como Safo: "La Noche y la Aurora tienen el mismo espíritu, pero distinto aspecto" 35 . Ese "descenso" al propio fondo, quizá nadie lo haya descrito mejor que Oscar Wilde, durante su oprobiosa época de reclusión: "Quiero vivir hasta que pueda explorar lo que desde ahora constituye un mundo nuevo para mí. $\mathrm{Y}$ este mundo es en el que he estado viviendo: el mundo del dolor, que ha de ser mi maestro y mi nueva aurora". Probablemente De profundis narre toda la hondura abismal a la que pueda conducir la experiencia erótica auténtica, el hallazgo difícil pero amoroso de sí mismo, de los secretos de la existencia, y el regreso a la aurora de la nueva vida con el corazón henchido de humildad. Él mismo ha definido a ésta, la más preciosa de las virtudes, como la aceptación de todas las experiencias.

Cuando el sufrimiento abismal del que habla Schopenhauer provoca en el hombre un súbito regreso a sí mismo, y una transformación que lo eleva por encima de todo dolor, lo encontramos consciente, liberado de la voluntad, pero tan alejado de la ilusión que para él es el mundo, que ya el amor no lo estremece. Y entonces ya no estamos ante el amante que tendrá que hacerle frente a la experiencia inevitablemente agridulce de lo erótico. Sabemos que el filósofo opinaba otras cosas sobre el amor, que se resumen en los artilugios de los que hace uso la naturaleza para que continúe la procreación de la especie. Los más apasionados romances de la poesía o de la vida no son más que ingeniosos medios de la phýsis para traer hijos a la existencia. El amor como creatio es otra mirada, tan antigua como la misma Diotima. Lo que ahora quiero decir es que el hombre redimido por su dolor, como el mismo filósofo lo describe, cuando regresa a la vida, aunque no se haya ennoblecido como el maestro imperturbable, es capaz de vivir y dar cuenta del amor desde el equilibrio que exige una experiencia cuya naturaleza es doble. Platón nos enseñó que esa duplicidad está en el alma, y por eso es erótica; Safo nos mostró a un Eros agridulce. Y el alma serena y dueña de sí misma es la que puede abrazar esa plenitud del amor. Sin drama y sin fantasías novelescas asume su naturaleza claroscura, con la humildad del que acepta todas las experiencias de la vida. Finalmente, tras el recorrido reflexivo a que invita el amor platónico, entramos en los territorios sosegados del equilibrio. El fragmento de Teognis antes citado, concentra el secreto amoroso cuando nos dice que mil males son ocasionados por su amado, pero también mil bienes, y que precisamente allí está la gracia y el deleite. Son "mil" (myría) males, pero también "mil" bienes; no tres mil males y doscientos bienes. El poeta deja muy claro con estas cifras idénticas que la aceptación de lo amargo no significa ennegrecerse la existencia; que la madurez de Perséfone que se hizo dueña de su tiniebla no la hunde cobardemente en ella. El horror despiadado de lo nocivo que se vuelve la

35 Frag. 3. 
implacable rutina, no es de lo que estamos hablando. Ese no es el amor agridulce o el equilibrio claroscuro. En ese caso, ya no estamos ante la experiencia erótica. Nos topamos con el alma vulgar, ausente de sí misma, con sus peores fuerzas desatadas, y sin ninguna inclinación erótica para asombrarse y conocer. Si la pena no cumple su labor de paideía, de regreso a uno mismo, si no remueve nuestro fango, al decir de Wilde, con la esperanza de una aurora, no es humidad lo que brota en el corazón, es cobardía. Enfrentarse a uno mismo para retornar embellecido al mundo, exige un profundo acto de valentía. Esa es la compleja experiencia erótica que guarda un compromiso con la epistème. Es curioso que un poeta use cifras para referirse al amor. Pero es la manera más contundente para decirnos que el deleite erótico no es unidimensional, es dulce y amargo, pero en equilibrio. Más aún, en un estricto equilibrio.

Si hemos hablado del dolor y la amargura no ha sido para hundirnos en ellos. Al menos no sin sentido, sin télos. Reconocidos como naturaleza de Eros, implican, a su vez, un doble movimiento: despertarnos del letargo como le ocurre al amante platónico, descender a nuestro fondo oscuro para hacernos dueño de él, y regresar con luz al devenir de la vida con la serenidad del que ama, del que es capaz de vivir el amor agridulce. Una voz profunda nos recuerda a Heráclito cuando nos dice que la phýsis de las cosas, aunque hechas de contrarios, es la misma. Es esta aceptación la exigencia que nos hace el mundo y sus fuerzas, la que nos pide el efesio, y también el amor agridulce de la poetisa. Heráclito nos llama dormidos y hasta incapaces de comprender la naturaleza del mundo. Pero la epistēme del dolor, de lo amargo, que culmina en la transformación y el equilibrio, nos regresa a la vida con el embellecimiento y la fortaleza del que ama con humildad y plenitud. Decía Jung que lograr el equilibrio de nuestros contrarios era "hallar la pieza maestra de la interioridad". El alma del filósofo amante nos lo muestra. Y lo más conmovedor de todo es que esta es el alma erótica capaz de conocer y filosofar.

$\mathrm{Si}$, como dice el Cantar de los cantares, "el deseo es despiadado como el sepulcro" 36 , hemos de regresar de esa muerte sintiendo en nuestra carne y sangre el milagro de la resurrección, y la gratitud de lo vivido. En ese fondo está la chispa de la aurora.

Nadie puede cerrar estas breves meditaciones, por honra y respeto, que el espíritu más grande de la "noche oscura", San Juan de la Cruz:

Aquesta viva fuente que deseo, en este pan de vida yo la veo, aunque es de noche.

368,6 . 


\section{Referencias bibliográficas}

BoERI, M. (2007): Apariencia y realidad en el pensamiento griego, Buenos Aires: Colihue, pp. 44 y ss.

Brioso, M. y Villarrubia, A. (2000): Consideraciones en torno al amor en la literatura de la Grecia Antigua, Sevilla: Publicaciones de la Universidad de Sevilla, pp. 11-78.

CARson, A. (1998): Eros the bittersweet: an essay, Canada: Paperback, pp.105-113. Calame, C. (2002): The Poetics of Eros in Ancient Greece, Princeton: Princeton University Press, pp. 20-51; 69-138; 175-189.

Calame, C. (2006): "Una poética de la memoria: espacio y tiempo en Safo", Ordia prima, ${ }^{\circ} 5$, pp. 19-35.

Cruz, M. (2013): Amo, luego existo, Buenos Aires: Eudeba, p. 14.

FERnÁNDEZ, M., LASSO, J., RodRÍGUEZ, F. (1959): El descubrimiento del amor en la Grecia Antigua, Madrid: Publicaciones de la Universidad de Madrid, pp. 9-10; $5-89$.

FERRATÉ, J. (2000): Líricos griegos arcaicos, Barcelona: El Acantilado, pp. 236269.

Fränkel, H. (1962): Poesía y filosofía de la Grecia Arcaica, Madrid: Visión, pp. 170-185.

Ferrari, G. (1992): "Platonic love" en Cambdridge Companion: Cambridge University Press, pp. 262-268.

García-BAró, M. (2004): De Homero a Sócrates, Salamanca: Sígueme, pp. 193194.

Humbert, J. (1995): Sócrates y los socráticos menores, Caracas: Monte Ávila, p. 84.

LanatA, G. (1966): "Sul linguaggio amoroso di Saffo", Quaderni Urbinati di Cultura Classica, no 6, pp. 63-79.

LANCElin, A. y Lemonnier, M. (2013): Los filósofos y el amor, Buenos Aires: Kairós, p. 9.

LESKY, A. (1989): Historia de la literatura griega, Madrid: Gredos, pp. 153-174.

LuQue, A. (2001): Los dados de Eros, Madrid: Hiperión, frag. 130.

Maltese, E. (2010): Platone, tutte le opere, Roma: Newton, Compton, Editori.

Nietzsche, F. (1981): Aurora, México: Editores mexicanos unidos, p. 1.

Page, D. (1955): Sappho and Alceus, Oxford: Clarendon Press, pp. 8-220.

PAтоČKA, J. (1991): Platón y Europa, Barcelona: Península, p. 84.

Pedrique, N. (2000): Safo: poesía del amor sagrado entre mujeres, Mérida: Universidad de los Andes, pp. 7-136;

RodríGueZ Adrados, F. (1971): "El campo semántico del amor, en Safo", Sociedad española de lingüística, 1, pp. 5-23; 
Rodríguez Adrados, F. (1981): El mundo de la lírica arcaica griega, Madrid: Alianza, pp. 123-142;

Rodríguez Adrados, F. (1995): Sociedad, amor y poesía en la Grecia Antigua, Madrid: Alianza, pp. 23-46; 130-146; 174-199; 206-217.

Rojas Parma, L. (2011): “De amore: Sócrates y Alcibíades en el Banquete de Platón”, en Areté, Pontificia Universidad Católica del Perú, vol. XXIII, 1.

Rougemont, D. (1999): Los mitos del amor, Buenos Aires: Kairós, 1999, p. 11.

Schadewaldt, W. (1973): Safo: Mundo y poesía, existencia en el amor, Buenos Aires: Eudeba.

Voltaire, (1995): Diccionario filosófico, Madrid: Temas de hoy, 1995, p. 128.

Lorena Rojas Parma

Escuela de Filosofía

Universidad Católica Andrés Bello (Venezuela)

lorojas@ucab.edu.ve 